\title{
O TEMOR DA ESCURIDÃO
}

Aline Lemes De Souza

Carine Vendruscolo

DOI: http://dx.doi.org/10.18616/intcov45

Escuridão, medo, incerteza, tragédia...

Aflição, insegurança, pavor, desespero...

Cenas de um filme de terror, o cenário de um novo mundo,

Sentimentos que afloram em meio a uma pandemia avassaladora,

Que com rapidez se espalhou globalmente,

Tornando todos reféns de um inimigo invisível e temerário.

Exposição, risco, estresse, cuidado, coragem...

Angústia, esperança, dedicação, heroísmo, exaustão...

Sentimentos no dia a dia de quem luta pela vida,

Que, incansavelmente, busca o sol em meio à escuridão,

Um sorriso no rosto, expresso pelo olhar,

Garantia de conforto, durante uma guerra sem previsão de fim.

Os profissionais de saúde merecem respeito,

Por nunca terem desistido,

Muitos adoeceram e até mesmo perderam a vida,

Nesses dias de luta, insaciável é a busca pelos dias de glória.

A ciência ainda investiga a melhor evidência,

Trazendo em meio a esses dias escuros,

Mais esperança e otimismo, confiantes na vitória. 
Essa é a interface da covid-19,

Tornando a sociedade em meio a pandemia refém de algo invisível, Tirou a liberdade de quem já tinha esse vislumbre,

$\mathrm{O}$ isolamento é prescrito, mas com efeitos danosos.

Pandemia com números expressivos, de todas as ordens,

E o mundo ainda na busca de apresto, para o desconhecido inimigo.

A crise econômica se tornou mundial,

Trouxe consigo muitas consequências,

Entre elas o desemprego.

Emerge, entretanto, uma importante reflexão: quem são os vulneráveis, afinal?

Essa é a realidade de quem vive essa pandemia,

Que ainda amedronta toda a nação, que busca o sol, pois hoje ainda é escuridão. 